\title{
PENINGKATAN AKTIVITAS DAN PRESTASI BELAJAR MAHASISWA MELALUI PEMBERIAN POST TEST PADA MATA KULIAH TELAAH KURIKULUM DAN PERANGKAT PEMBELAJARAN BIOLOGI SEKOLAH MENENGAH ATAS DENGAN PENDEKATAN TERPADU
}

\author{
Nur Rokhimah Hanik ${ }^{1}$, Sri Harsono ${ }^{2}$, Tri Wiharti ${ }^{3}$ \\ Pendidikan Biologi, FKIP, Universitas Veteran Bangun Nusantara Sukoharjo \\ E-mail: nurhanik03@gmail.com
}

\begin{abstract}
Abstrak
Tujuan penelitian ini untuk meningkatkan aktivitas dan prestasi belajar mahasiswa pada mata kuliah Telaah Kurikulum dan Perangkat Pembelajaran Biologi SMA melalui pemberian post-test dengan pendekatan terpadu. Harapannya akan diperoleh suatu strategi dan model pembelajaran yang sesuai untuk mengatasi kurangnya aktivitas dan rendahnya prestasi belajar mahasiswa yang disebabkan oleh jumlah mahasiswa putri yang dominan. Penelitian ini merupakan penelitian tindakan kelas dengan 3 siklus. Tiap siklus terdiri atas 4 tahapan dasar yaitu perencanaan, tindakan, observasi, dan refleksi. Pengumpulan data penelitian menggunakan lembar observasi dan tes. Teknik analisis data menggunakan teknik analisis deskriptif. Dari hasil penelitian diperoleh nilai rata-ratahasil belajar siklus I: 78,75tuntas 85\% nilai aktivitas 3,72, siklus II: 68,64 tuntas 50\% nilai aktivitas 3,4, dan siklus III: 80,45 tuntas 100\% dan nilai aktivitas 3,82 semakin terjadi peningkatan yaitu mulai 3,47, 3,72 , 3,75 dan 3,82. Dengan demikian dapat disimpulkan bahwa dengan pemberian post-test dan pendekatan terpadu dapat meningkatkan aktivitas dan hasil belajar mahasiswa
\end{abstract}

Kata kunci: Aktivitas , Prestasi Belajar, pendekatan Terpadu

\section{PENDAHULUAN}

Peran dosen dalam meningkatkan kualitas harus didukung oleh kompetensi yang dimiliki dosen. Rustaman (2006: 6) menyatakan bahwa peran pendidik dalam pembelajaran di kelas diperlukan penguasaan sejumlah kompetensi yang mendukung, yaitu kompetensi pedagogik, kompetensi profesional, kompetensi kepribadian, dan kompetensi sosial. Sebagai wujud dari penguasaan kompetensi ini, setiap tindakan dosen dalam mengelola pembelajaran merupakan tindakan pengambilan keputusan yang dapat dipertanggungjawabkan secara keilmuan, profesional dan secara moral. Dosen dalam kegiatan perkuliahan juga memiliki tugas untuk memberi evaluasi atau tes yang berfungsi untuk mengetahui hasil belajar mahasiswa. Selain itu evaluasi atau tes juga untuk mengetahui kesesuaian perencanaan yang telah dirumuskan dalam tujuan pembelajaran khusus (TKP) yang tertera dalam kurikulum.

Djohar (1985) menyatakan bahwa pendidik yaitu dosen mempunyai dua fungsi sebagai instruktur dan pendidik. Sebagai instruktur, dosen memberikan pedoman belajar yang jelas bagi mahasiswa, memberi petunjuk, mengarahkan, mengkondisikan belajar, serta menyediakan perangkat kerja yang diperlukan dalam kegiatan 


\section{JEMS (Jurnal Edukasi Matematika dan Sains)}

Tersedia online di: http://e-journal.ikippgrimadiun.ac.id/index.php/JEMS

Volume 4, Nomor 1, Maret 2016, hal 1 - 7

pembelajaran. Sedangkan sebagai pendidik, dosen harus mampu mengetahui permasalahan dalam proses pembelajaran atau perkuliahan sebagai upaya untuk memperbaiki kualitas pembelajaran di kelas.

Hasil pengamatan dalam proses pembelajaran mata kuliahmata kuliah Anatomi Tumbuhan (yang peneliti ampu) pada semester III tahun akademik 2014/2015 di Program Studi Pendidikan Biologi Universitas Veteran Bangun Nusantara Sukoharjo ditemukan beberapa permasalahan tentang aktivitas belajar mahasiswa. Selama proses pembelajaran dengan diskusi informasi maupun dengan pendekatan komparasi, mahasiswa masih kurang konsentrasi, masih ditemukannya beberapa mahasiswa yang bermain Handphone (HP), sebagian mahasiswa membuat gaduh di dalam kelas, berdiskusi di luar materi pembelajaran. Mahasiswa program studi pendidikan biologi semester III angkatan 2013 berjumlah 22 orang yang terdiri dari 20 orang mahasiswa putri dan 2 orang mahasiswa putra. Jumlah mahasiswa yang didominasi oleh putri mengindikasikan banyaknya diskusi atau pembicaraan yang menjurus pada diskusi di luar topik materi pembelajaran.

Permasalahan aktivitas belajar mahasiswa merupakan permasalahan penting yang perlu diselesaikan. Sardiman (2004: 96) mengungkapkan bahwa aktivitas pembelajaran penting guna mendukung keberhasilan pembelajaran. Aktivitas pembelajaran yang sering gaduh tersebut mengakibatkan rendahnya prestasi belajar mahasiswa semester III. Prestasi belajar mahasiswa (Uji tengah sem) pada mata kuliah Anatomi Tumbuhan semester gasal 2014/2015 diperoleh rata-rata 57,3 yang tergolong rendah/cenderung rendah dan mahasiswa yang belum tuntas sebanyak 10 orang. Sedangkan nilai ujian semester gasal diperoleh rata-rata yaitu 65,2 dan mahasiswa yang belum tuntas sebanyak 6 orang. Akar masalah dalam pembelajaran tersebut adalah belum adanya pembelajaran yang dapat memotivasi mahasiswa untuk lebih aktif dalam proses pembelajaran. Sebagai dosen profesional dituntut untuk mampu menguasai berbagai pendekatan/model/metode pembelajaran yang sesuai untuk mengatasi permasalahan pembelajaran. Salah satu solusi yang dipilih untuk mengatasi permasalahan pembelajaran tersebut adalah dengan menerapkan pendekatan pembelajaran terpadu.

Pendekatan terpadu ini merupakan pendekatan yang intinya memadukan dua unsur atau lebih dalam suatu kegiatan pembelajaran. Unsur pembelajan yang dipadukan dapat berupa konsep dengan proses, konsep dari satu mata pelajaran dengan konsep mata pelajaran lain, atau dapat juga berupa penggabungan suatu metode dengan metode lain. Pemaduan dilakukan dengan menekankan pada prinsip keterkaitan antar satu unsur dengan unsur lain, sehingga diharapkan terjadi peningkatan pemahaman yang lebih bermakna dan peningkatan wawasan karena satu pembelajaran melibatkan lebih dari satu cara pandang (Gnanakan, 2013 dan Rustaman, N.Y dkk., 2004 ).

Pembelajaran terpadu merupakan suatu pendekatan yang berorientasi pada praktik pembelajaran yang sesuai dengan kebutuhan perkembangan anak. Pendekatan ini berangkat dari teori pembelajaran yang menolak proses latihan/hafalan (drill) sebagai dasar pembentukan pengetahuan dan struktur intelektual anak. Teori pembelajaran ini dimotori para tokoh Psikologi Gestalt, (termasuk teori Piaget) yang menekankan bahwa pembelajaran itu haruslah bermakna dan menekankan juga pentingnya program pembelajaran yang berorientasi pada kebutuhan perkembangan anak.

Pelaksanaan pendekatan pembelajaran terpadu ini bertolak dari suatu topik atau tema yang dipilih dan dikembangkan oleh pendidik bersama-sama dengan peserta didik. Tujuannya bukan hanya untuk menguasai konsep-konsep mata pelajaran, akan tetapi konsep-konsep dari mata pelajaran terkait dijadikan sebagai alat dan wahana untuk mempelajari dan menjelajahi topik atau tema. Jika dibandingkan dengan pendekatan konvensional, maka pembelajaran terpadu lebih menekankan pada keterlibatan peserta didik dalam proses belajar atau mengarahkan anak secara aktif terlibat dalam proses pembelajaran dan pembuatan keputusan. Pendekatan

\section{2 | Peningkatan Aktivitas Dan Prestasi Belajar Mahasiswa Melalui Pemberian ...}




\section{JEMS (Jurnal Edukasi Matematika dan Sains)}

Tersedia online di: http://e-journal.ikippgrimadiun.ac.id/index.php/JEMS

Volume 4, Nomor 1, Maret 2016, hal 1 - 7

pembelajaran terpadu ini lebih menekankan pada penerapan konsep belajar sambil melakukan sesuatu (learning by doing) (Wrenn, 2009).

Terdapat beberapa karakteristik yang perlu Anda pahami dari pembelajaran terpadu. 1) Pembelajaran terpadu berpusat pada peserta didik (student centered). Pendekatan sesuai dengan pendekatan belajar modern yang lebih banyak menempatkan pebelajar sebagai subjek belajar. Peran pendidik lebih banyak sebagai fasilitator yaitu memberikan kemudahan-kemudahan kepada peserta didik untuk melakukan aktivitas belajar. 2) Pembelajaran terpadu dapat memberikan pengalaman langsung kepada peserta didik (direct experiences). Pengalaman langsung memberi kesempatan kepada peserta didik berhadapan pada sesuatu yang nyata (konkrit) sebagai dasar untuk memahami halhal yang lebih abstrak. 3) Pembelajaran terpadu pemisahan antar mata pelajaran menjadi tidak begitu jelas. 4) Pembelajaran terpadu menyajikan konsep-konsep dari berbagai mata pelajaran dalam suatu proses pembelajaran. Peserta didik dapat memahami konsep-konsep tersebut secara utuh. Hal ini diperlukan untuk membantu peserta didik dalam memecahkan masalah-masalah yang dihadapi dalam kehidupan sehari-hari. 5) Pembelajaran terpadu bersifat luwes (fleksibel), sebab pendidik dapat mengaitkan bahan ajar dari satu mata pelajaran dengan mata pelajaran yang lainnya, bahkan dengan kehidupan peserta didik dan keadaan lingkungan dan tempat sekolah. 6) Hasil pembelajaran dapat berkembang sesuai dengan minat dan kebutuhan peserta didik.

Gnanakan (2013) dan Triyanto dalam Putra dkk, (2013) menyatakan bahwa pada pembelajaran terpadu dapat membangun dan menghubungkan dua atau lebih materi pembelajaran menjadi satu kesatuan yang lebih efektif. Dua komponen pada pembelajaran terpadu adalah memadukan beberapa teori/ ilmu pengetahuan dan konsep-konsep tentang kehidupan yang nyata. Lebih lanjut Gnanakan (2013) mengatakan bahwa pendekatan/model terpadu menjadikan pembelajaran lebih bermakna, karena dapat meningkatkan minat pada beberapa aspek. Pada pembelajaran terpadu menghubungkan beberapa macam komponen akademik; materi pembelajaran, guru, kondisi kelas, siswa dan kehidupan nyata.

Sa'ud, dkk. (2006) dan menjelaskan pendekatan terpadu memiliki beberapa keunggulan atau kekuatan dibandingkan dengan model pembelajaran konvensional, diantaranya adalah; 1) mendorong guru untuk mengembangkan kreatifitas; 2) memberikan peluang bagi guru untuk mengembangkan situasi pembelajaran yang utuh, menyeluruh, dinamis dan bermakna sesuai dengan keinginan dan kemampuan guru maupun kebutuhan dan kesiapan siswa; 3) mempermudah dan memotivasi siswa untuk mengenal, menerima, menyerap, dan memahami keterkaitan atau hubungan antara konsep, pengetahuan, nilai atau tindakan yang terdapat dalam beberapa pokok bahasan atau bidang studi; 4) menghemat waktu, tenaga dan sarana serta biaya pembelajaran, disamping menyederhanakan langkah-langkah pembelajaran.

Bonwell dan Eison dalam (Jan Wrenn dan Bruce Wrenn, 2009) bahwa pembelajaran terpadu antara teori dan praktek termasuk belajar aktif sehingga; siswa lebih terlibat dari pada sekedar mendengarkan pelajaran, pemindahan pengetahuan lebih mengembangkan ketrampuilan siswa, siswa dapat berfikir pada taraf tingkat tinggi (analisis, sintesis dan evaluasi), siswa dapat melakukan aktivitas belajar (menulis, membaca, diskusi dan observasi), dan penekanan siswa pada saat eksplorasi adalah diperolehnya kemampuan sikap dan nilai-nilai.

Mata kuliah Telaah Kurikulum dan Perangkat Pembelajaran Biologi SMA. Mata kuliah Telaah Kurikulum dan Perangkat Pembelajaran Biologi SMA merupakan mata kuliah semester IV yang harus ditempuh dan dikuasai oleh mahasiswa. Selain itu mata kuliah tersebut juga merupakan mata kuliah prasarat dalam menempuh mata kuliah Microteaching dan Program Pengalaman Lapangan (PPL). Mata kuliah tersebut memiliki muatan materi cukup banyak, terutama membahas tentang macam kurikulum sekolah, dan perangkat pembelajaran. Materi tentang perangkat pembelajaran 
JEMS (Jurnal Edukasi Matematika dan Sains)

Tersedia online di: http://e-journal.ikippgrimadiun.ac.id/index.php/JEMS

Volume 4, Nomor 1, Maret 2016, hal 1 - 7

memerlukan banyak latihan atau strategi work shop. Sehingga karakteristik mata kuliah Telaah Kurikulum dan Perangkat Pembelajaran Biologi SMA sesuai dengan pembelajaran terpadu.

Pembelajaran terpadu menurut Collin dkk (1991:2) menekankan pengalaman belajar dalam konteks yang bermakna. Pembelajaran terpadu menekankan pada pemberian teori di dalam kelas yang terintegrasi secara langsung dengan praktek/workshop. Pendekatan pembelajaran terpadu memberi manfaat diantaranya mahasiswa dapat memahami materi karena dalam proses pembelajaran, mahasiswa dituntut untuk praktek langsung setelah menerima teori sehingga retensi pengetahuan dapat bertahan lama. Selain itu untuk meningkatkan prestasi dan aktivitas belajar mahasiswa juga diberikan post-test yangdiberikan disetiap akhir pertemuan.

Pemberian posttest diakhir perkuliahan diharapkan mahasiswa termotivasi untuk aktif dalam proses pembelajaran karena mahasiswa akan berusaha untuk memperoleh nilai post-test yang tinggi sebagai produk hasil belajar disetiap pertemuan. Tes formatif atau posttest juga merupakan salah satu cara atau sarana untuk mengetahui tingkat penguasaan materi atau sebagai alat untuk mengukur prestasi belajar mahasiswa. Roediger (2006: 254) mengungkapkan bahwa pemberian tes tidak hanya untuk mengukur kemampuan mahasiswa tetapi juga meningkatkan retensi pengetahuan karena mahasiswa mengerjakan tes sama dengan mengkaji kembali materi yang telah dipelajari. Fatmawati (2012) dalam penelitiannya menyimpulkan bahwa dengan adanya pemberian pre-test dan post-test dengan model pembelajaran mampu meningkatkan hasil belajar peserta didik.

Penelitian ini memiliki tujuan untuk meningkatkan aktivitas dan prestasi belajar mahasiswa pada mata kuliah Telaah Kurikulum dan Perangkat Pembelajaran Biologi SMA melalui pemberian post-test dengan pendekatan terpadu. Harapannya akan diperoleh suatu strategi dan model pembelajaran yang sesuai untuk mengatasi kurangnya aktivitas dan rendahnya prestasi belajar mahasiswa yang disebabkan oleh jumlah mahasiswa putri yang dominan sehingga iklim kelas sering gaduh dan konsentrasi berkurang pada saat pembelajaran.

\section{METODE PENELITIAN}

Penelitian dilaksanakan mulai bulan Februari 2015 sampai bulan Mei 2015. Subjek dalam penelitian adalahmahasiswa program studi pendidikan Biologi Angkatan tahun 2013 (Semester IV tahun akademik 2014/2015) sebanyak 22 orang dan TIM dosen mata kuliah Telaah Kurikulum dan Perangkat Pembelajaran Biologi SMA sebanyak 3 orang. Bentuk dan strategi dalam penelitian ini yaitu penelitian yang digunakan adalah Penelitian Tindakan Kelas (PTK). Sumber data dalam penelitian tindakan kelas ini adalah mahasiswa semester IV yang menempuh mata kuliah Telaah Kurikulum dan Perangkat Pembelajaran Biologi SMA serta TIM dosen mata kuliah sebagai observer. Dalam penelitian ini, untuk mendapatkan data yang tepat, digunakan alat pengumpul yang berupa instrument test dan lembar observasi. Sedangkan teknik analisis yang dilakukan dalam penelitian adalah deskriptif kualitatif. Teknik tersebut dilakukan karena sebagian besar data yang dikumpulkan dalam penelitian berupa uraian deskriptif tentang perkembangan proses, yakni peningkatan aktivitas dan prestasi belajar mahasiswa.

a. Hasil belajar dianalisis dengan analisis diskriptif komparatif yaitu membandingkan nilai tes antar siklus maupun dengan indikator kinerja. b.Observasi dengan analisis diskriptif kualitatif berdasarkan hasil observasi dan refleksi. Target atau hasil yang diharapkan harus dicapai dari kegiatan ini adalah perbaikan atau peningkatan kualitas pembelajaran pada mata kuliah Telaah Kurikulum dan Perangkat Pembelajaran Biologi SMA, dengan indikator :

Untuk aktivitas belajar mahasiswa : a. keaktifan dalam presentasi $b$. keaktifan dalam mengajukan pendapat c. keaktifan dalam bertanya d. keaktifan dalam menjawab pertanyaan e. keaktivan mendengarkan pendapat orang lain. Sedangkan untuk prestasi belajar mahasiswa berupa nilai ulangan / post-test. Prosedur penelitian siklus pertama dengan materi perumusan tujuan pembelajaran yang meliputi

\section{4 | Peningkatan Aktivitas Dan Prestasi Belajar Mahasiswa Melalui Pemberian ...}




\section{JEMS (Jurnal Edukasi Matematika dan Sains) \\ Tersedia online di: http://e-journal.ikippgrimadiun.ac.id/index.php/JEMS \\ Volume 4, Nomor 1, Maret 2016, hal 1 - 7}

perencanaan, pelaksanaan tindakan, observasi dan refleksi, Siklus ke-2 dan ke- 3 dengan materi tentang penyusunan materi ajar dan Lembar Kegiatan Siswa. Pelaksanaan siklus ke-2 dan ke3 , rencana tindakan, pelaksanaan tindakan, observasi, dan refleksi didasari dari refleksi tindakan pada siklus sebelumnya, dengan berbagai penyempurnaan untuk memperoleh hasil yang optimal.

\section{HASIL PENELITIAN DAN PEMBAHASAN}

Hasil penelitian dari 3 siklus yang telah dilaksanakan dapat dilihat pada tabel 1 dan table 2 .

Tabel 1. Perbandingan Nilai Aktivitas hasil siklus I, II, dan III.

\begin{tabular}{ccc}
\hline Siklus & $\begin{array}{c}\text { Rata-rata Nilai aktivitas } \\
\text { diskusi }\end{array}$ & $\begin{array}{c}\text { Kategori aktivitas } \\
\text { diskusi }\end{array}$ \\
\hline I & 3,75 & Sangat aktif \\
II & 3,4 & Sangat aktif \\
III & 3,82 & Sangat aktif \\
\hline
\end{tabular}

Tabel 2. Perbandingan Nilai Posttest hasil siklus I, II, dan III.

\begin{tabular}{cccc}
\hline $\begin{array}{c}\text { Nilai } \\
\text { post test } \\
\text { tertinggi }\end{array}$ & $\begin{array}{c}\text { Nilai post } \\
\text { test terendah }\end{array}$ & $\begin{array}{c}\text { Rata-rata } \\
\text { post test }\end{array}$ & Jumlah Tuntas \\
\hline 100 & 40 & 78,75 & $17 / 85 \%$ \\
100 & 50 & 68,64 & $11 / 50 \%$ \\
90 & 70 & 80,45 & $22 / 100 \%$ \\
\hline
\end{tabular}

Kenaikan hasil pada siklus I, II, III dan IV tersebut (tabel 1) disebabkan dalam kegiatan pembelajaran ini dosen melaksanakan pembelajaran dengan berorientasi pada kebutuhan peserta didik. Pemilihan aktivitas pembelajaran menjadi penting bagi dosen untuk menciptakan pengalaman yang bermakna bagi mahasiswa. Pada pembelajaran mata kuliah Telaah Kurikulum dan Perangkat Pembelajaran ini diterapkan pendekatan terpadu, dimana pendekatan terpadu merupakan suatu pendekatan yang berorientasi pada praktik pembelajaran yang sesuai dengan kebutuhan perkembangan anak. Pendekatan ini berangkat dari teori pembelajaran yang menolak proses latihan/hafalan (drill) sebagai dasar pembentukan pengetahuan dan struktur intelektual anak. Teori pembelajaran ini dimotori para tokoh Psikologi Gestalt, (termasuk teori Piaget) yang menekankan bahwa pembelajaran itu haruslah bermakna dan menekankan juga pentingnya program pembelajaran yang berorientasi pada kebutuhan perkembangan anak.

Pelaksanaan pendekatan pembelajaran terpadu ini bertolak dari suatu topik atau tema yang dipilih dan dikembangkan oleh pendidik bersama-sama dengan peserta didik. Tujuannya bukan hanya untuk menguasai konsep-konsep mata pelajaran, akan tetapi konsep-konsep dari mata pelajaran terkait dijadikan sebagai alat dan wahana untuk mempelajari dan menjelajahi topik atau tema. Jika dibandingkan dengan pendekatan konvensional, maka pembelajaran terpadu lebih menekankan pada keterlibatan peserta didik dalam proses belajar atau mengarahkan anak secara aktif terlibat dalam proses pembelajaran dan pembuatan keputusan. Pendekatan pembelajaran terpadu ini lebih menekankan pada penerapan konsep belajar sambil melakukan sesuatu (Gnanakan, 2013 dan Bonwell dan Eison dalam (Jan Wrenn dan Bruce Wrenn, 2009). Pada pembelajaran mata kuliah ini para mahasiswa secara kelompok dua orang diajak untuk melakukan work shop dalam pembuatan perangkat pembelajaran, mulai dari pembuatan atau perumusan Tujuan Pembelajaran, penyusunan Materi Ajar, dan penyusunan Lembar Kegiatan Siswa. Mereka diajak bekerja dan berdiskusi serta presentasi hasil kerja mereka, sehingga mereka tidak mempunyai kesempatan untuk mengobrol ataupun asyik bermain HP 


\section{JEMS (Jurnal Edukasi Matematika dan Sains)}

Tersedia online di: http://e-journal.ikippgrimadiun.ac.id/index.php/JEMS

Volume 4, Nomor 1, Maret 2016, hal 1 - 7

sendiri karena jika demikian maka tugas mereka tidak akan selesai.

Selain diterapkannya pembelajaran terpadu ternyata pemberian post-test setelah pembelajaran juga memacu mereka untuk serius dalam proses pembelajaran yang berorientasi work shop, karena jika mereka asyik bermain dan ngobrol sendiri secara otomatis maka pemahaman mereka akan materi kuliah semakin jelek, dan hasil belajarnya juga kurang memuaskan. Ini sesuai pendapat dari Arikunto ( 2010: 150) bahwa pemberian post-test diakhir perkuliahan memiliki manfaat yaitu mahasiswa termotivasi untuk aktif dalam proses pembelajaran karena mahasiswa akan berusaha untuk memperoleh nilai post-test yang tinggi sebagai produk hasil belajar disetiap pertemuan. Selain itu post-test juga dapat dijadikan umpan balik bagi dosen untuk perbaikan proses pembelajaran.

Rosa (2006) menjelaskan bahwa penilaian post-test adalah metode yang digunakan oleh unit-unit akademik di mana tes yang dikembangkan secara lokal dan ujian yang diberikan di awal dan di akhir kursus atau program akademik. Hasil tes ini memungkinkan fakultas untuk memantau perkembangan siswa dan belajar sepanjang periode waktu yang ditentukan. Hasilnya sering berguna untuk menentukan di mana keterampilan dan kekurangan pengetahuan yang ada dan paling sering berkembang. Roediger, et al (2006: 254) mengungkapkan bahwa pemberian tes tidak hanya untuk mengukur kemampuan mahasiswa tetapi juga meningkatkan retensi pengetahuan karena mahasiswa mengerjakan tes sama dengan mengkaji kembali materi yang telah dipelajari.

Pada penelitian ini, evaluasi berupa posttest berbentuk essai. Jelaslah bahwa setelah adanya tes akan diketahui adanya umpan balik antara mahasiswa maupun dosen yang mengajar. Setelah itu diharapkan adanya perbaikan masingmasing baik mahasiswa maupun dosen. Sistem evaluasi dosen perlu mengintensifkan pelaksanaan tes akhir (post-test), karena tes akhir (post-test) yang dilakukan secara sistematis diharapkan dapat memperbaiki kualitas proses pembelajaran yang pada gilirannya bermuara pada peningkatan hasil belajar mahasiswa. Tes sebagai alat pengukur dan penilaian hasil belajar dapat memiliki manfaat, antara lain; sebagai diagnosis dan remedial untuk mengukur kekuatan dan kelemahan seseorang dalam rangka memperbaiki penguasaan atau kemampuan dalam suatu program pendidikan tertentu (Asmawi dan Nochi dalam Pujani, 2006).

Maka jelaslah jika dalam penelitian ini dimana pembelajaran pada mata kuliah Telaah Kurikulum dan Perangkat Pembelajaran yang menerapkan pendekatan terpadu dan pemberian post-test diakhir pembelajaran membuat mahasiswa aktif bekerja dan serius dalam proses pembelajaran sehingga para mahasiswa tidak ada kesempatan untuk ngobrol dan asyik dengan kegiatannya sendiri serta serius untuk menghadapi post-test diakhir perkuliahan, sehingga prestasi belajarnya mereka cukup bagus meskipun pada siklus ke dua terjadi penurunan dibanding siklus pertama namun pada siklus ketiga $100 \%$ mereka mengalami tuntas belajar dengan tara-rata nilai post-test 80,45

\section{KESIMPULAN}

Simpulan pada penelitian ini adalah, pemberian post-test dan pendekatan terpadu pada mata kuliah Telaah Kurikulum dan Perangkat Pembelajaran sangat bagus untuk meningkatkan aktivitas dan prestasi belajar. Pada siklus kedua terjadi sedikit penurunan prestasi belajar dibanding dengan siklus kedua, oleh karena itu perlu dikaji lebih dalam oleh tim dosen dan mahasiswa dimana letak kekurangan atau kelemahan proses pembelajarannya.

\section{DAFTAR PUSTAKA}

Arikunto, S. 2010. Dasar-Dasar Evaluasi Pendidikan (Edisi Revisi). Jakarta: Bumi Aksara. . (2010). Penelitian Tindakan Kelas. Jakarta: Bumi Aksara.

Collin, Gillian dan Hazel Dixon. 1991. Integrated Learning Planed Curriculum Units, Australia Books Shelf Publising.

\section{6 | Peningkatan Aktivitas Dan Prestasi Belajar Mahasiswa Melalui Pemberian ...}


JEMS (Jurnal Edukasi Matematika dan Sains)

Tersedia online di: http://e-journal.ikippgrimadiun.ac.id/index.php/JEMS

Volume 4, Nomor 1, Maret 2016, hal 1 - 7

Djohar. 1985. Sejarah Pendidikan Sains dan Implikasinya bagi Pengembangan Konsep Belajar Mengajar IPA. Cakrawala Pendidikan. No. 2 Volume IV 1985. IKIP Yogyakarta.

Fatmawati, Alimatu. 2012. Efektivitas Pemberian Pretes Dan Postes Pada Model Pembelajaran Ctl Sebagai Upaya Peningkatan Hasil Belajar Tentang Massa Jenis. Jurnal Berkala Fisika Indonesia. Volume 4 Nomor $1 \& 2$.

Gnanakan, Ken. 2013. The Integrated Learning Experience. William Carey InternationalDevelopment JournalVol 2, Issue 1: Winter 2013 diakses dari http://www.wciujournal.org/ uploads/files/ Gnanakan.pdf pada hari Selasa 9 Pebruari 2016 jam 22.05

Wrenn, J and Bruce Wrenn. 2009. Enhancing Learning by Integrating Theory and Practice. International Journal of Teaching and Learning in Higher Education. 2009, Volume 21, Number 2, 258-265. ISSN 1812-9129diakses dari http://www.isetl.org/ijtlhe/ pada hari selasa 9 Pebruari 2016 jam 22.25

Putra, I Gd. Agus Mayga, Murda, I Nym., Agustiana I G. A. Tri.2013. Pengaruh Model Pembelajaran Terpadu Tipe Connected Berbantuan Media Gambar Terhadap Hasil Belajar Ipa Siswa Kelas
IV Sd. Diakses dari http://ejournal. undiksha.ac.id/index.php/JJPGSD/ article/viewFile/ 918/788 (pembelajaran terpadu)

Pujani, M. 2006. Peningkatan Kualitas Perkuliahan Termodinamika dengan Mengintensifkan Penggunaan Tes Formatif .Jurnal Pendidikan dan Pengajaran IKIP Negeri Singaraja. No 1.Th XXXIX. Januari 2006. Fakultas Pendidikan MIPA-IKIP Negeri Singaraja.Bali.

Roediger,H.L III, and Jeffrey D. Karpicke. 2006. Test-Enhanced Learning. Research Article of Association for Psychological Science. Volume 17-Number 3.

Rustaman, N.Y dkk. 2004. Strategi Belajar Mengajar Biologi. Bandung: Jurusan Pendidikan Biologi FPMIPA UPI. . 2005. Stategi belajar Mengajar Biologi. Malang: UM Press.

Rosa, Santa. 2006. Assessment Handbook. Methods of Assessment: Direct and Indirect

Sardiman. 2004. Interaksi dan Motivasi Belajar Mengajar. P.T Raja Grafindo Persada : Jakarta.

Sa’ud. Dkk. 2006. Pembelajaran Terpadu. Bandung: UPI Press 